\title{
Ancestry Culture, Assimilation, and Voter Turnout in Two Generations
}

\author{
Henning Finseraas ${ }^{1}$ (D) Andreas Kotsadam ${ }^{2} \cdot$ Javier Polavieja $^{3}$ \\ Published online: 9 May 2020 \\ (c) The Author(s) 2020
}

\begin{abstract}
Women vote less than men in many parts of the world. Whether this gender gap is due to cultural preferences stemming from traditional gender norms or to structural constraints is hard to answer because preferences and beliefs are endogenous to the socioeconomic and institutional environment. To address this problem, we use the so-called epidemiological approach. This approach exploits the portability of culture as a source of identification, by comparing migrants from different cultures of origin but living in similar institutional environments. We study the gender patterns in turnout of immigrants and their children in Norway using administrative register data on voter turnout. We find that gender traditionalism at country of origin is significantly correlated with the gender gap in the first generation, but has no effect in the second generation. Together, our results suggest that early institutional exposure is important for political assimilation.
\end{abstract}

Keywords Voter turnout · Immigration · Gender equality

Henning Finseraas

henning.finseraas@ntnu.no

Andreas Kotsadam

andreas.kotsadam@frisch.uio.no

Javier Polavieja

javier.polavieja@uc3m.es

1 Norwegian University of Science and Technology, Po box 8900, Torgarden, 7491 Trondheim, Norway

2 The Ragnar Frisch Centre for Economic Research, Oslo, Norway

3 Universidad Carlos III de Madrid, Madrid, Spain 


\section{Introduction}

Early studies of electoral behavior in Western democracies commonly found that women were less likely to vote than men (Lipset 1960; Campbell et al. 1960; Welch 1977). The gender gaps in turnout were reasonably consistent up until roughly the last quarter of the 20th century. Since then, these gaps have been drastically reduced and today they have practically disappeared in all advanced democracies. In some countries (e.g. US, Sweden, Norway), they have actually reversed (Seppälä 2004). Women, however, still vote less than men in many poor countries, particularly in those where traditional gender norms prevail (see e,g, Inglehart and Norris 2003, Chap. 5; Isaksson et al. 2014; Solijonov 2016). Also, even in some of the most advanced Western democracies, women from older generations tend to vote less than their male counterparts (CAWP 2017; Norris 2002). These findings are consistent with the marked and well-documented shift in gender role attitudes that took place in virtually all affluent societies throughout the second half of the 20th century, but which was not observed to the same degree in many developing countries (Inglehart and Norris 2003).

The early studies of the 1960s and 1970s gave two types of explanations for women's lower turnout in Western democracies. The first explanation emphasized political socialization, particularly early parental socialization, as the main driver of gender differences in political participation. The original arguments all boiled down to the idea that women were socialized to be home-oriented and, as a consequence, less interested in, knowledgeable of, and involved with political matters belonging to the public sphere (e.g. Campbell et al. 1964). This explanation therefore stressed the role of internalized gender norms transmitted through processes of political socialization (i.e. cultural transmission). Gender gaps in turnout were thus explained as a reflection of internalized traditional beliefs regarding the appropriate roles of men and women in society, which we can call gender culture for short. The second explanation stressed in turn women's situational constraints. Although these constraints ultimately stemmed from their taking up traditional gender roles as wives, mothers and caregivers, the thrust of these so-called situational explanations was that it was the structural barriers women faced and not their own internalized preferences and attitudes that explained the observed gender gaps in political participation. In other words, the argument went, if women had equal opportunities to be exposed to public matters, their political behavior would converge with men's (Pomper 1975; Almond and Verba 2015; Welch 1977).

Fifty years down the road, the relative importance of cultural preferences and beliefs vis-à-vis situational factors in explaining gender differences in political behavior is still not well understood. This is because people's cultural preferences and beliefs are endogenous to their social environment, that is, they are affected by the same institutions and situational conditions that constrain individuals' actions and shape their experiences. Early attempts to test the role of preferences against situational factors (e.g. Welch 1977) disregard the problem of endogenous preferences. And yet the question these early attempts aimed to answer remain as 
relevant today. What explains gender differences in turnout in the countries where these differences still hold? Is it the transmission of gender traditionalism understood as a set of preferences, beliefs and norms, or is it the different institutions and structural constraints women and men face? Because societies differ along economic, institutional and cultural dimensions, and because these dimensions co-vary, we cannot infer causal relationships by simply comparing country level outcomes. To empirically identify the effect of culture on political behavior, we need to separate its influence from that of institutions and other correlated factors. This poses a very important challenge for the identification of cultural effects.

To address this challenge, we exploit the portability of culture as a key source of causal identification. Peoples' cultural preferences and beliefs can be transported across different institutional contexts through migration and this offers a unique opportunity to tackle the problem of endogenous preferences (for a discussion see Polavieja 2017). We rely on the so-called epidemiological approach (Fernández and Fogli 2009; Fernández 2011) to identify the role of traditional cultural beliefs on gender differences in voting turnout. The idea behind the epidemiological research design is to examine people with different cultures facing the same formal institutions. When people migrate from their origin countries to a new host society, they take some aspects of their culture of origin with them, but now migrants are facing a new institutional environment. This new environment cannot possibly affect the culture of origin. Migration thus decouples culture and institutions and, in so doing, provides the opportunity to identify exogenous cultural effects on people's behavior. In other words, migration allows us to observe how culture operates in isolation from all other situational factors and constraints. This requires observing the behavior of people from different cultures facing the same institutions. We use high quality administrative register data from Norway on both voter turnout and country origins at the individual level and examine the behavior of both first and second generation migrants from across the globe. The second generation is particularly useful to study, because parents transfer cultural norms, but not institutions, from the country of origin.

The nature of our data enables a rich analysis of the relationship between ancestry culture and gender differences in turnout. The key challenge of inference we face is to avoid that our cultural measures capture other aspects of the origin/ancestry country which are unrelated to gender preferences and norms but which could potentially influence migrants' behavior (in this case voting behavior). Such concerns have sparked a debate about the assumptions inherent in the analysis of culture using the epidemiological approach (Chou 2017; Polavieja 2017). One specific concern in the context of this study is that countries with high support for traditional gender roles tend to also be countries with shorter democratic histories, which implies lower levels of "democratic capital" (Fuchs-Schündeln and Schündeln 2015). Democratic capital is correlated with political participation (Fuchs-Schündeln and Schündeln 2015), thus, crude measures of gender culture at origin might pick up part of the impact of democratic capital. Our data and empirical approach allow us to account for differences in democratic capital together with all other stable factors at the country of origin level. More specifically, we estimate regression models with either country or family fixed effects to identify the impact of gender culture on the 
propensity to vote. By design, our specifications control for omitted characteristics which are correlated with culture, but uncorrelated with sex, which increases the plausibility that our estimates pick up the net influence of attitudes related to gender roles. $^{1}$

By analyzing political participation, we add to the recent and growing literature on the importance of culture in gendered outcomes. Recent contributions using the epidemiological approach have concluded that culture matters for female employment in both the first (Polavieja 2015) and the second generation (Fernández and Fogli 2009; Fernández 2007; Finseraas and Kotsadam 2017; Polavieja 2015) but, to our knowledge, this is the first application of the epidemiological approach to the analysis of gender differences in political behavior. Moving beyond labour market outcomes to social outcomes is important to understand how hardwired cultural beliefs are.

Our study also contributes to the immigrant assimilation literature. ${ }^{2}$ Early assimilation research considered cultural assimilation ("acculturation") as a crucial step in the socio-economic integration of immigrants (see Gordon 1964; Gans and Sandberg 1973). New assimilation models, however, question the sequential logic of early assimilation theories by stressing that socio-economic integration might precede (or even occur without) cultural assimilation, and that assimilation might take place in some aspects of culture but not in others (see Alba and Nee 2003). ${ }^{3}$ The study of political participation has not been central to these debates on how to best conceptualize immigrants' incorporation to the destination society, yet participation in the political mainstream seems particularly relevant to this literature because it can be seen as both an outcome of assimilation as well as a resource for socioeconomic integration. Political participation can be an important resource for the socio-economic integration of migrants and their descendants by making the political system responsive to their needs and interests (see e.g. Vernby 2013). There is, however, little knowledge on the relative influence of culture of origin and experience at destination for the political integration of migrants and their descendants, as most research focuses on differences in individual socio-economic characteristics and the propensity to vote (see e.g. Rooij and Eline 2012; Voicu and Comsa 2014). Perhaps the paper closest to our study is Wass et al. (2015). They study the impact of individual-level indicators of structural and identificational assimilation, together with the democratic history of the country of origin, on migrants' voting propensity. Their interest, however, is with the determinants of migrants' overall levels of

\footnotetext{
1 See Finseraas and Kotsadam (2017) for an empirical application of these designs to the study of labor market outcomes.

${ }^{2}$ In line with the migration literature, we use the term assimilation to refer to the process whereby minority groups become increasingly similar in their preferences and behaviors to the majority population, while we use the term social integration to refer to the processes of socio-economic incorporation of minorities to the destination country (see e.g. Alba and Nee 1997).

3 In new assimilation models, cultural integration is seen as neither inevitable nor necessarily intentional. Indeed documented processes of cultural retention or "encapsulation" and cultural reactivation question the straight-line notion of assimilation typical of the early sociological accounts (see e.g. Alba and Nee 2003; Battu et al. 2006; Güveli and Platt 2011).
} 
political participation (including the role of both exposure to destination institutions and democratic culture of origin) but not with gender differences in turnout linked to ancestry culture. Their study is also restricted to the first generation immigrants. We add to this literature by investigating the role of ancestry culture in explaining gender differences in political participation, by studying assimilation patterns across generations, and by bringing the problem of endogenous preferences to the fore of the discussion on the effect of culture on political behavior.

We find that culture of ancestry (gender traditionalism) is correlated with the gender difference in voter turnout, but only in the first generation. In the second generation, the gender culture of ancestry has no observable effects on turnout. Our results thus show that assimilation on this aspect of culture from the first to the second generation is very strong, and in fact appears to be much stronger than assimilation in labor market outcomes (Finseraas and Kotsadam 2017).

\section{Institutional setting}

In the main analyses of this study we focus on turnout in local elections. Parliamentary elections receive a greater level of public interest, but important parts of welfare service provision are decentralized to the municipal level, so these elections are not unimportant. Local elections take place every four years, midway through the national election cycle. Voters elect representatives to municipal and county councils using a proportional representation (PR) system. Voter turnout is high at about $60 \%$ in 2015 . Voter registration is automatic and information about the election and the closest polling place is sent out by mail. Immigration to Norway has increased markedly over the recent decades and the native immigrant gap in turnout is substantial (Bratsberg et al. 2019a, b; Ferwerda et al. 2018). Most importantly for our purposes, non-citizens are allowed to vote in local elections and eligibility rules for foreign nationals in local elections are among the most liberal in Europe. On the basis of reciprocal agreements, citizens of Nordic countries gain voting rights after less than three months of residence, while, since 1983, all other foreign nationals with at least three years of continuous legal residence have the right to vote.

We also study turnout in national elections in some additional analyses. National elections take place every four years. There are 19 election districts, which elect representatives using PR. ${ }^{4}$ Turnout, $78 \%$ in 2013, is high in comparative perspective. Norwegian citizens have the right to vote from the year they turn 18. Immigrants can apply for Norwegian citizenship after seven years of residence. Dual citizenship is not allowed (with some exceptions) and Norway does not practice citizenship by birth if parents are not Norwegian citizens. As we have voting data for a larger sample from the local elections and as immigrants are allowed to vote earlier after arrival in these elections, we will mainly focus on local elections.

\footnotetext{
${ }^{4}$ Candidates are chosen by political parties in a closed-list system (no voter influence). Eight parties achieved representation after the 2013 election that we study in this paper.
} 
Table 1 Turnout in the 2015 election for different samples

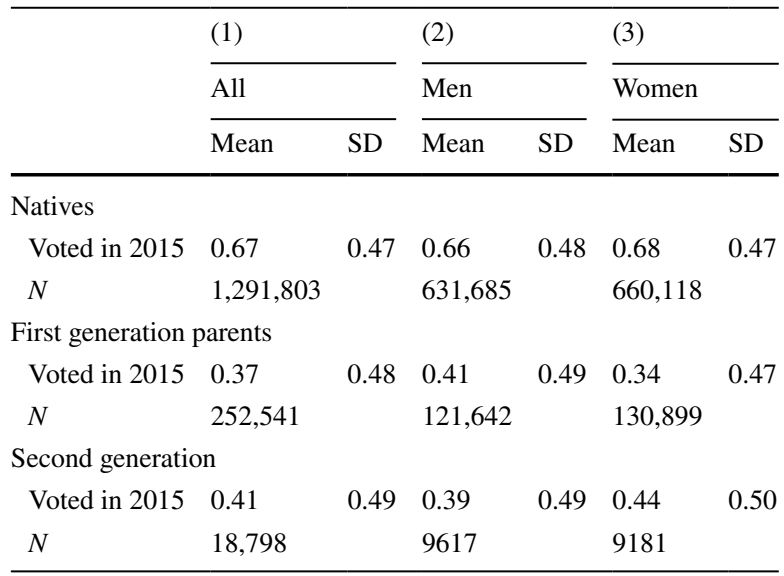

\section{Data}

We rely on data from merged administrative registers, encrypted to prevent identification of individuals, which are collected, administered, and made available for research by Statistics Norway. The data set includes validated voting records free from recall and social desirability bias in measuring voter turnout. The turnout data cover the 27 municipalities (in 2015) which had electronic records of turnout. ${ }^{5}$ As the largest municipalities have electronic records, we have 1.7 out of 4 million eligible voters in the dataset. ${ }^{6}$ Using unique identifiers for individuals, Statistics Norway merged the data with other administrative registers, before handing it over to us with encrypted IDs. The linked data set contains rich background information at the individual level, including demographics, level of education, family identifiers, tax records and labor market history. Data from these administrative records are less fraught with measurement errors and attrition than similar data collected from surveys.

Our data include information on country of ancestry of first and second generation immigrants, and we can link individuals to their parents and siblings. Our sample of second generation immigrants are born in the years 1941-1999 for which we observe turnout in 2013 and 2015. For ease of interpretation and strength of cultural input from parents, we define a second generation immigrant as a person born in Norway with two foreign-born parents from the same country. To examine to what degree the strict definition of a second generation immigrant affects our estimate of culture, we also present results using a lax definition where we define second generation as having at least one foreign-born parent. Using this definition we allow

\footnotetext{
5 The data on voter turnout in the 2013 National election only covers 13 municipalities.

6 The levels of turnout in the electronic record samples are representative of the turnout levels in the full population.
} 
Table 2 Descriptive statistics for the main independent variables. Second generation immigrants sample

\begin{tabular}{llll}
\hline & $(1)$ & & \\
\cline { 2 - 4 } & Mean & SD & $\mathrm{N}$ \\
\hline FLFP 1970 & 16.41 & 12.05 & 18,798 \\
Logged FLFP & 2.51 & 0.76 & 18,798 \\
Female turnout & 0.45 & 0.25 & 14,077 \\
$N$ & 18,798 & & \\
\hline
\end{tabular}

having parents from different countries, where country of ancestry refers to the mother's country of birth if the parents have different origins.

Our outcome variable is a binary indicator of whether the individual voted. We see in Table 1, that 44 (34)\% of female second (first) generation immigrants in our sample voted in the 2015 election, while 39 (41)\% of the men did so. The table also shows that turnout is higher among natives. The average turnout across immigrants is however less interesting than the huge variation across ancestry countries. In Appendix Table 5, we present a list of ancestry countries, lagged female labor force participation rates and female voting in the ancestry country (the share of women saying they always vote in national elections, see below), as well as their respective turnout in Norway. We also see in the table that Pakistan is the ancestry country with the highest number of second generation immigrants, with about one third of the sample. Some countries have very few individuals in our sample.

\section{Proxies for Culture}

To measure culture we want indicators that are related to gender equality in general and to gender equality in political participation in particular. Our first measure of gender equality culture is the female labor force participation rates (FLFPR) in the country of ancestry in 1970, as reported in the International Labor Organization's (ILO) ILOSTAT Database (ILO 2014). ${ }^{7}$ Country differences in FLFPR nicely capture variation in the division of gender roles between the domestic (private) and the economic (public) sphere across different societies. Societies where women participate less in the labor market display a more traditional distribution of gender roles (for a review see Fernandez 2011). As seen in Table 2, the mean FLFPR across the countries in our main sample is 16.41 (2.51 for Log FLFPR), with a standard deviation of $12.05(0.76)$. In the estimations, we take the natural log of FLFPR since it makes intuitive sense that a one percentage point difference in FLFPR will have a larger impact at low levels of FLFPR. This measure of gendered culture is widely used in the literature and generally correlates with other aspects of gender equality (Fernández and Fogli 2009; Fernández 2011; Finseraas and Kotsadam 2017).

\footnotetext{
${ }^{7}$ Coverage declines if we lag FLFPR further back in time.
} 


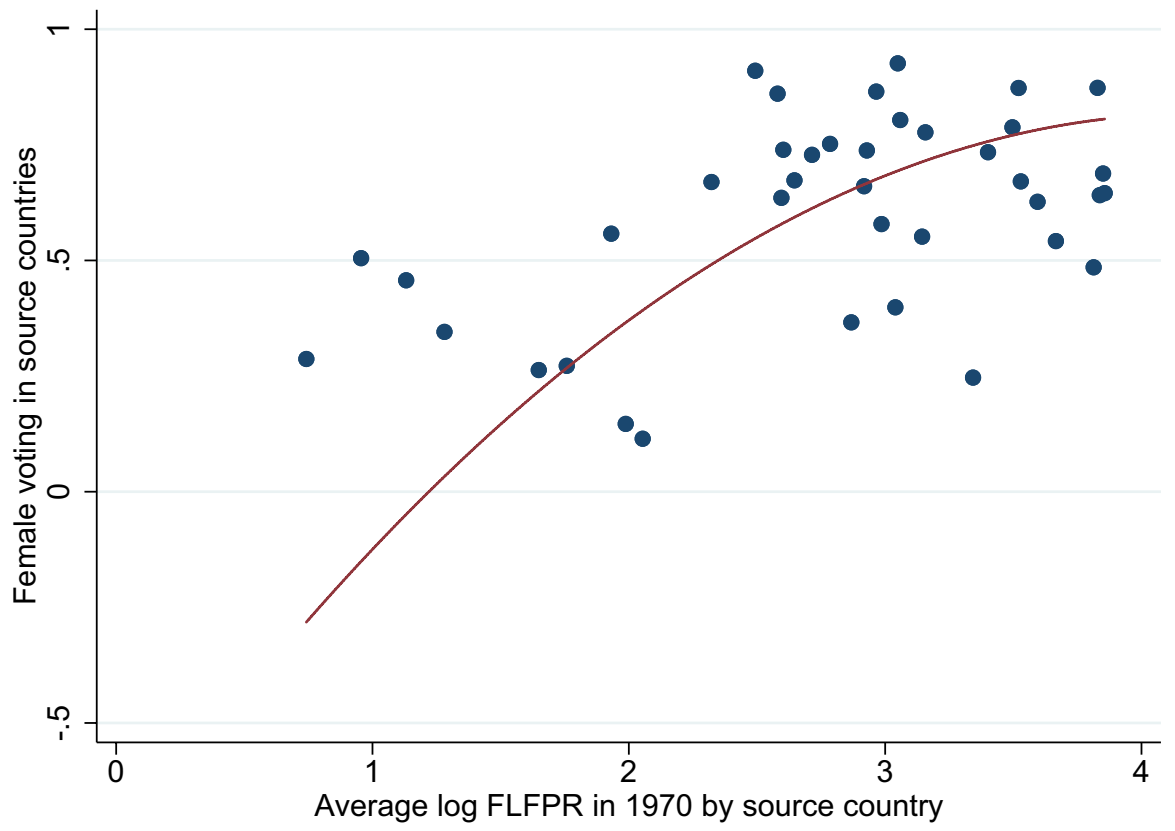

Fig. 1 Correlation between the two main measures of ancestry culture. The line shows the estimated relationship between the two measures based on a curvelinear regression model. The dots in the figure refer to the mean values on the two measures in each different country

Our second measure is a proxy for the female turnout in the ancestry country. Unfortunately, official statistics on turnout by sex exist only for very few countries. To the best of our knowledge, the largest set of countries for which there is comparable data is the World Values survey. ${ }^{8}$ We use the sixth round of the World Values Survey and measure female turnout as the share of women answering "Always" to the question "When elections take place, do you vote always, usually or never? National elections". The variable is only available in the sixth round. The measure is directly related to the political culture in the ancestry country, but we have a considerably smaller coverage when using this measure. Table 2 shows that the mean female turnout is $45 \%$, while Fig. 1 shows that there is a strong correlation between the two measures of gender culture.

\section{Empirical Strategy}

To estimate the relationship between culture of ancestry and turnout we rely on two approaches. The first is a regression model with country of ancestry fixed effects, where we explore whether the gender gap in turnout between men and women in

\footnotetext{
8 Another alternative, used by e.g. Norris (2002), could have been to use data from the Comparative Study of Electoral Systems but it includes fewer countries.
} 
Norway depends on our measures of gender culture in the ancestry country. By including the country fixed effects and comparing men and women we control for all ancestry related factors which influence men and women in the same manner (e.g. democratic capital), and we then ascribe the remaining variation to differences in gender culture. ${ }^{9}$ Specifically, we estimate the following regression:

$$
\text { Voted }_{i c}=\text { BFemale }_{i c}+\gamma \text { Female }_{i c} * \text { Culture }_{c}+\alpha_{c}+\text { YoB }_{i c}+\epsilon_{i c},
$$

where individual i has a background in ancestry country c. As described above, culture is measured using either lagged female labor force participation or female vote share in the country of ancestry. We mean-center the proxies for gender culture so that the female coefficient $\beta$ refers to the gender gap at mean-levels of gender culture. Since gender culture does not vary across immigrants from the same country, the culture variable is perfectly collinear with the country fixed effects. This means that the "main effect" of culture cannot be estimated. However, the interaction with gender can be estimated since we have men and women from the same country. The interaction term $\gamma$ shows whether the gender gap covaries with culture. In all models we control for year of birth (YoB). We estimate robust standard errors adjusted for clustering at country of ancestry since our measures of culture vary at this level. ${ }^{10}$

The second approach is a sibling comparison approach where we restrict the analysis to a sample of siblings and replace the country fixed effects with sibling fixed effects. By comparing siblings of different sex, we are controlling for all factors that affect male and female siblings the same. This includes effects related to childhood environment, parental networks, time since immigration, and neighborhood characteristics, as long as they have the same effects on male and female siblings. The variation retained in the sibling fixed effects models is by construction that part of lagged FLFPR or female turnout that affects daughters and sons differently, which we argue is a plausible estimate of cultural effects on gender roles (see also Finseraas and Kotsadam 2017).

\section{Culture and Turnout Among the First Generation Immigrant Parents}

Results for the parental first generation immigrants in Norway are presented in Table 3. We focus on first-generation parents to better identify potential transmission/assimilation processes across the first and the second generation. Results for all first-generation respondents are, however, presented in Appendix Table 7.

\footnotetext{
${ }^{9}$ Migrants face the same national host institutions but some groups could face some specific barriers and constraints. By including the country fixed effects and comparing men and women, we control for all such destination-specific factors affecting women and men in the same manner. Hence if particular groups face specific barriers in Norway (e.g. discrimination, low human capital information deficits due to linguistic distance), this should also be captured by our specification.

${ }^{10}$ We prefer OLS/linear probability models to probit/logit models since interaction terms can be difficult to interpret in non-linear models (Ai and Norton 2003). Nonetheless, Tables 12 and 13 in the Appendix show that we get the same conclusion if we use a non-linear specification.
} 


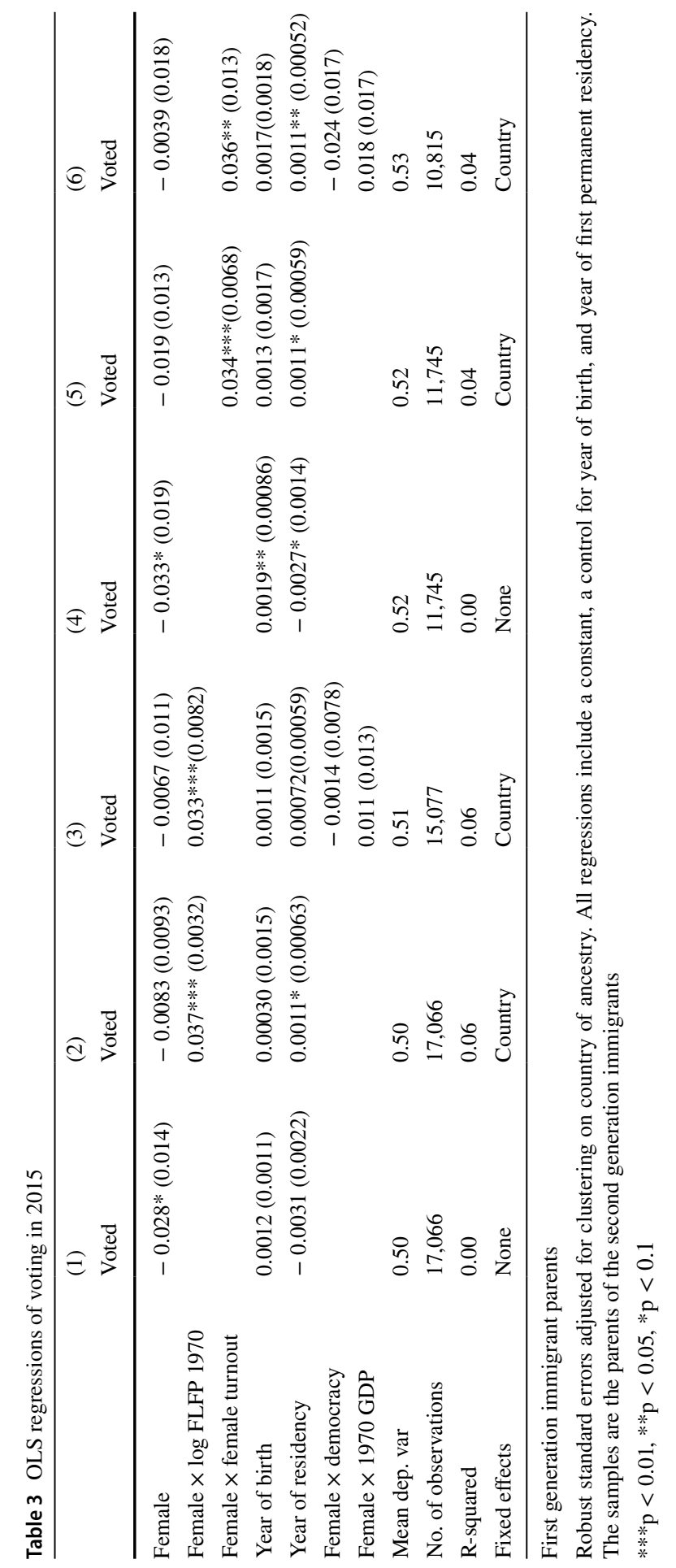


Columns 1 and 4 in Table 3 show that first-generation immigrant mothers in Norway are on average less likely to vote than fathers. The difference is around 3 percentage points, and only statistically significant at the $10 \%$ level [p-values: .054 (column 1); .091 (column 4)]. This modest difference is not surprising given that many migrants in the sample come from countries with no gender gaps in political participation. What is key for our purposes is to explore the variation across country of origin and the correlation between gender traditionalism at origin and political participation in Norway. To this end, we interact our measures of culture with voters' own gender, which tests whether the gender gap varies with the cultural proxies, and in addition include country fixed effects.

We find that both measures of ancestry culture are differentially correlated with the propensity to vote. Gender traditionalism at the country of ancestry reduces women's propensity to vote significantly more than it reduces men's, as revealed by the interaction terms (see columns 2 and 5). ${ }^{11}$ This means that the voting gender gap in favor of men is larger (smaller) the more traditional (gender equal) the culture in the origin country. This is true whether we measure origin culture using lagged FLFPR or female vote share. The conclusion is robust to controls for interactions between gender and democratic history and GDP (in columns 3 and 6), which are potential confounders since they might determine both turnout and gender culture. ${ }^{12}$

In Appendix Table 7 we study the full sample of first generation immigrants. Here we find that women are on average more, not less, likely to vote than men, which likely reflects the greater demographic weight of advanced Western democracies in the full sample (e.g. students and young childless professionals from Scandinavian and other European countries). Yet the cultural effects are still visible. As the interaction terms show, the gender gap is more in favor of women in gender egalitarian countries, and less in favor of women in gender inegalitarian countries.

\section{Turnout in the Second Generation}

So far our findings have shown an effect of origin culture on voting turnout for the first generation parents. Women coming from more gender traditional cultures tend to vote less than their male counterparts, as it was the case in may Western societies half a century ago. But what happens in the second generation? Does the cultural effect last?

\footnotetext{
${ }^{11}$ We control for year of first permanent residency as the composition of the immigrant population has changed over time. Moreover, length of stay is correlated with turnout and to some extent with gender (because males arrive before females). Appendix Table 6 shows that the results are similar, but stronger if we remove this control.

12 GDP likely correlates with gender differences in educational attainment which, in turn, might lead to different voting patterns by sex. Whether democratic experience in the country of origin will have an effect on gender-gaps in turnout is admittedly less obvious. Our concern, however, is that small differences in the costs of voting by gender might play a larger (smaller) role for voters with low (high) levels of democratic capital, thus leading to gender differences in turnout through channels not directly linked to gender culture.
} 


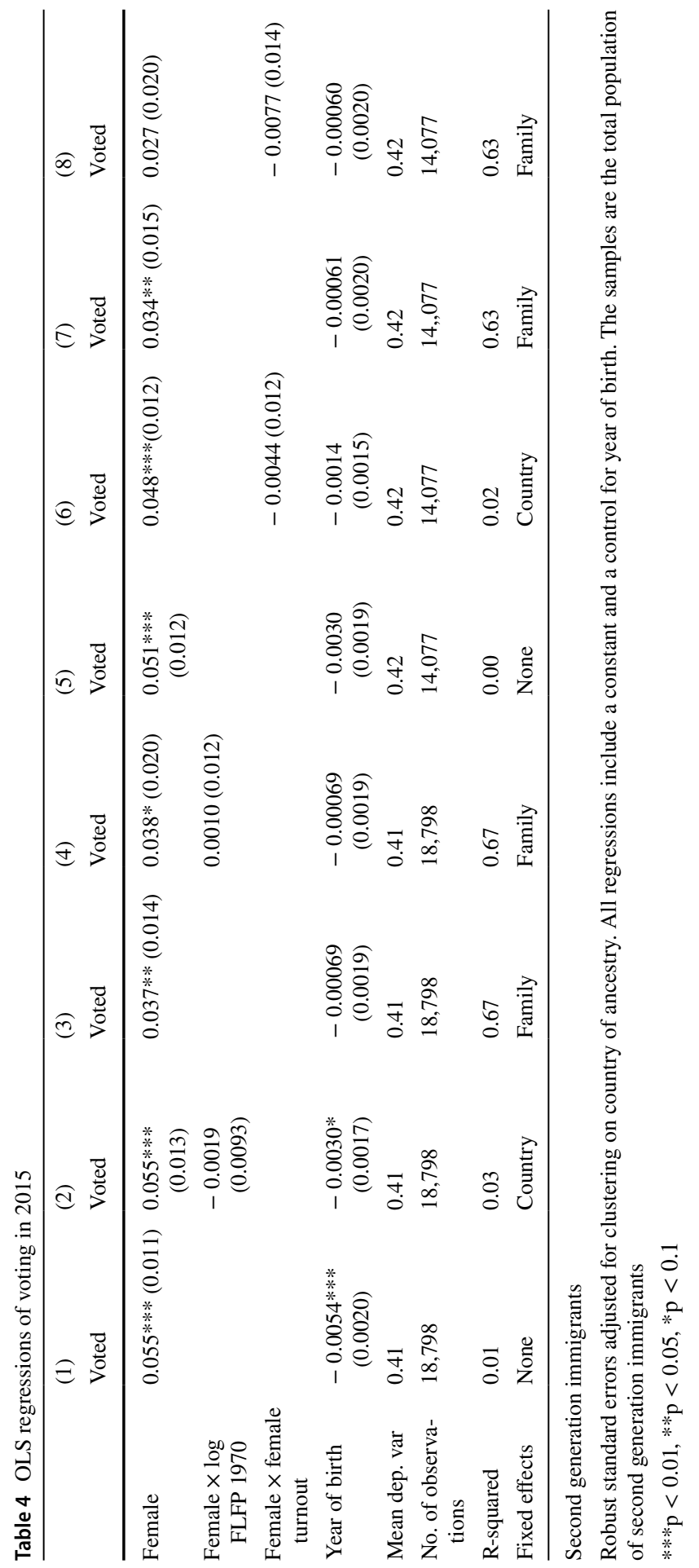


Table 4 reports the main results for immigrant children in Norway. In columns 1 and 5 we find that the gender gap is on average around 5-5.5 percentage points in favor of women, a difference that is similar to that for the native population. Next we again include country fixed effects and interact our measures of culture with the gender dummy. Now we find that neither lagged FLFPR (column 2) nor the female vote share (column 6) at the country of ancestry is important. The interaction term is small in size and statistically insignificant.

In columns 3 and 7 we add the family fixed effects and thus rely on sibling variation. The estimated gender gap declines to about 3.5 percentage points, which suggests unobserved family and neighborhood factors contribute positively to the size of the gender gap. In columns 4 and 8 we again interact the measures of culture with gender. The precisely estimated interaction terms show that the sister-brother difference does not vary with lagged FLFPR or female vote share in the country of ancestry.

These results are robust to adding additional controls (Appendix Table 8), ${ }^{13}$ to changing the definition of second generation immigrants (Appendix Table 9), to different codings of the main independent variables (Appendix Table 10) and to investigating turnout in national rather than local elections (Appendix Table 11). In Appendix Tables 12 and 13 we show that the results are very similar if we present marginal effects after logit specifications instead of linear probability models. Appendix Table 13 further shows that results are similar if we restrict the sibling fixed effects models to only include individuals with siblings in the sample.

\section{Concluding Remarks}

Early studies of electoral behavior in Western democracies found that women were less likely to vote than men. Although these gaps have practically disappeared (if not reversed) in all advanced Western democracies, women still vote less than men in many parts of the world. The classic studies of the 1960s and 1970s offered two explanations for women's lower turnout, one stressed political socialization in traditional gender roles, the other stressed women's situational constraints (Welch 1977). Yet the relative importance of each of these factors was never properly estimated because early studies simply lacked the conceptual and methodological tools to address the so-called problem of endogenous preferences, that is, the inconvenient fact that people's values, beliefs and preferences are always shaped by the social environments in which they are embedded. The problem of endogenous preferences means that separating out the effect of gender

\footnotetext{
13 More precisely, we include sibling fixed effects and we further include controls for the share of democratic years and GDP per capita in 1970 in the ancestry country interacted with female.
} 
preferences and beliefs from that of situational constraints is practically impossible when individuals are observed in their social contexts.

To address this problem, we exploit the portability of culture as a key source of identification using the so-called epidemiological approach. The epidemiological approach allows us to capture cultural effects by studying immigrants with different cultures of ancestry observed in the same social environment. To our knowledge, we are the first to explicitly implement this approach to the study of political behavior. We are also the first to document gender cultural and assimilation effects on turnout using high-quality administrative data, thereby avoiding the well-known problems with surveying immigrant groups and of measuring voter turnout (but see also Wass et al. 2015).

Our study of the variation among immigrant groups suggest that gender traditionalism is important for explaining the gender gap in turnout among parents in the first generation of immigrants. Specifically, we show that culture of ancestry correlates significantly with the gender gap in turnout in the first generation so that the more traditional the country of origin, the more likely it is that men vote in larger numbers than women. This result is robust to controls for democratic history and GDP at country of origin, which reinforces a cultural interpretation of the observed turnout patterns in Norway. Yet we do not observe this cultural effect in the second generation. Although turnout rates of migrants in the second generation are still significantly lower than those found for natives, gender gaps in participation have vanished. Hence, the data show there is a clear process of assimilation over generations, whereby gender culture ceases to play a significant role in determining the participation patterns of immigrant children.

One explanation for these findings is that early exposure to the receiving country's institutions is important. By being born and raised in the host country, the second generation is exposed to Norwegian institutions and gender norms during their entire childhood, when both their gender roles (Kotsadam and Finseraas 2013; Platt and Polavieja 2016; Polavieja and Platt 2014) and their political behavior (Denny and Doyle 2008; Finseraas 2017; Holbein 2017) may be more easily influenced.

As with other epidemiological approaches to the study of cultural effects, we stress our interest with migration is not only substantive but also strategic. We focus on migrants because they make identification of cultural effects more plausible. Had we observed our voters in their respective countries of origin, it would have been impossible to elucidate whether gender differences in turnout patterns responded to gender norms (cultural factors) or structural constraints (situational factors). Epidemiological approaches offer an innovate take on this problem and 
hence a promising avenue of research on the cultural determinants of political behavior. That the cultural effect with respect to gender disappears in one single generation suggests that the second generation is already embedded in the institutions and norms of the destination society. But once embedded, the problem of endogenous preferences reemerges and the possibility of correctly identifying the relative import of (Norwegian) culture and (Norwegian) institutions wanes.

The results speak to both the expanding literature on the epidemiological approach to study culture, as well as to the literature on political participation, thus bridging two fields of research hitherto disconnected. Moreover, our findings speak to the broader literature on cultural assimilation. In particular, our results show that the political assimilation of immigrant women in Norway is much quicker than labor market assimilation (Fernández and Fogli 2009; Fernández 2011; Finseraas and Kotsadam 2017). Whether the observed patterns of assimilation can travel outside the Norwegian context we cannot tell. We suspect, however, that Norwegian institutions could be particularly conducive to rapid political assimilation in regards to gender outcomes, given the strong emphasis placed on gender equalization policies in all areas, including political representation. An increasing number of countries have access to administrative data on voter turnout, and we urge researchers to examine the intergenerational transmission of culture in other countries, to examine potential cross-national variation in these patterns. Having comparative evidence on assimilation processes would allow for a richer investigation of the separate and interactive roles of both institutions and culture in determining political behavior.

Acknowledgements Open Access funding provided by NTNU Norwegian University of Science and Technology (incl St. Olavs Hospital - Trondheim University Hospital).

Funding Funding from the Norwegian Research Council Grant Number 270772 is acknowledged.

Open Access This article is licensed under a Creative Commons Attribution 4.0 International License, which permits use, sharing, adaptation, distribution and reproduction in any medium or format, as long as you give appropriate credit to the original author(s) and the source, provide a link to the Creative Commons licence, and indicate if changes were made. The images or other third party material in this article are included in the article's Creative Commons licence, unless indicated otherwise in a credit line to the material. If material is not included in the article's Creative Commons licence and your intended use is not permitted by statutory regulation or exceeds the permitted use, you will need to obtain permission directly from the copyright holder. To view a copy of this licence, visit http://creativecommons.org/licen ses/by/4.0/.

\section{Appendix}

See Tables 5, 6, 7, 8, 9, 10, 11, 12, and 13 . 
Table 5 Summary statistics across ancestry countries

\begin{tabular}{|c|c|c|c|c|c|}
\hline Country & FLFP & Logged FLFP & Female turnout & $\begin{array}{l}\text { Turnout in } \\
\text { Norway }\end{array}$ & $\mathrm{N}$ \\
\hline Algeria & 2.1 & 0.74 & 0.29 & 0.34 & 59 \\
\hline Argentina & 19.4 & 2.97 & 0.87 & 0.75 & 4 \\
\hline Austria & 31 & 3.43 & - & 0.75 & 4 \\
\hline Bangladesh & 7.2 & 1.97 & - & 0.60 & 70 \\
\hline Belgium & 21.9 & 3.09 & - & 0.14 & 7 \\
\hline Bosnia & 30.7 & 3.42 & - & 0.30 & 461 \\
\hline Brazil & 13.2 & 2.58 & 0.86 & 0.50 & 4 \\
\hline Bulgaria & 46.6 & 3.84 & - & 0.33 & 6 \\
\hline Canada & 27.5 & 3.31 & - & 0.67 & 6 \\
\hline Cape Verde & 34.3 & 3.54 & - & 0.44 & 66 \\
\hline Chile & 16.2 & 2.79 & 0.75 & 0.32 & 595 \\
\hline Colombia & 14.1 & 2.65 & 0.67 & 0.50 & 14 \\
\hline Costa Rica & 11 & 2.40 & - & 0 & 3 \\
\hline Cote d'Ivoire & 58.8 & 4.07 & - & 0 & 4 \\
\hline Croatia & 30.7 & 3.42 & - & 0.30 & 148 \\
\hline Cyprus & 23.5 & 3.16 & 0.78 & 1 & 1 \\
\hline Czech Republic & 42.3 & 3.74 & - & 0.67 & 36 \\
\hline Denmark & 34.1 & 3.53 & - & 0.58 & 313 \\
\hline Dominican Republ & 15.9 & 2.77 & - & 0.25 & 4 \\
\hline Ecuador & 10.2 & 2.32 & - & 0.33 & 9 \\
\hline Egypt & 3.6 & 1.28 & 0.35 & 0.20 & 20 \\
\hline El Salvador & 13.8 & 2.62 & - & 0.46 & 13 \\
\hline Faeroe Islands & 18.5 & 2.92 & - & 0.75 & 12 \\
\hline Finland & 37.5 & 3.62 & - & 0.44 & 41 \\
\hline France & 28.7 & 3.36 & - & 0.54 & 13 \\
\hline Germany & 30 & 3.40 & 0.73 & 0.63 & 111 \\
\hline Ghana & 34.1 & 3.53 & 0.67 & 0.41 & 128 \\
\hline Greece & 21 & 3.04 & - & 0.50 & 8 \\
\hline Guatemala & 8.2 & 2.10 & - & 0.25 & 4 \\
\hline Honduras & 7.8 & 2.05 & - & 0.86 & 7 \\
\hline HongKong & 28.3 & 3.34 & 0.25 & 0.33 & 80 \\
\hline Hungary & 38.6 & 3.65 & - & 0.64 & 145 \\
\hline Iceland & 25.3 & 3.23 & - & 0.45 & 88 \\
\hline India & 13.5 & 2.60 & 0.74 & 0.42 & 1154 \\
\hline Indonesia & 22.5 & 3.11 & - & 0.36 & 14 \\
\hline Iran & 6.4 & 1.86 & - & 0.38 & 616 \\
\hline Iraq & 6.9 & 1.93 & 0.56 & 0.36 & 350 \\
\hline Ireland & 20 & 3 & - & 0.67 & 3 \\
\hline Italy & 19.6 & 2.98 & - & 0.68 & 22 \\
\hline Japan & 39.1 & 3.67 & 0.54 & 1 & 1 \\
\hline Jordan & 2.6 & 0.96 & 0.51 & 0 & 2 \\
\hline Korea & 23.2 & 3.14 & 0.55 & 0.44 & 18 \\
\hline
\end{tabular}


Table 5 (continued)

\begin{tabular}{|c|c|c|c|c|c|}
\hline Country & FLFP & Logged FLFP & Female turnout & $\begin{array}{l}\text { Turnout in } \\
\text { Norway }\end{array}$ & $\mathrm{N}$ \\
\hline Kosovo & 30.7 & 3.42 & - & 0.19 & 477 \\
\hline Kuwait & 5.2 & 1.65 & 0.26 & 0.50 & 2 \\
\hline Macedonia & 30.7 & 3.42 & - & 0.22 & 353 \\
\hline Madagascar & 47.8 & 3.87 & - & 0.57 & 7 \\
\hline Malaysia & 20.9 & 3.04 & 0.40 & 0 & 5 \\
\hline Mauritius & 12.1 & 2.49 & - & 0.54 & 24 \\
\hline Mexico & 10.2 & 2.32 & 0.67 & 1 & 2 \\
\hline Morocco & 7.8 & 2.05 & 0.11 & 0.39 & 1288 \\
\hline Nepal & 25.9 & 3.25 & - & 0 & 1 \\
\hline Netherlands & 18.7 & 2.93 & 0.74 & 0.70 & 86 \\
\hline Nigeria & 17.6 & 2.87 & 0.37 & 0.43 & 77 \\
\hline Pakistan & 5.8 & 1.76 & 0.27 & 0.45 & 6809 \\
\hline Peru & 12.1 & 2.49 & 0.91 & 0.39 & 18 \\
\hline Philippines & 21.3 & 3.06 & 0.80 & 0.30 & 400 \\
\hline Poland & 46.4 & 3.84 & 0.64 & 0.42 & 327 \\
\hline Portugal & 19 & 2.94 & - & 0.70 & 10 \\
\hline Romania & 47 & 3.85 & 0.69 & 0.60 & 10 \\
\hline Russia & 45.3 & 3.81 & 0.49 & 0.64 & 11 \\
\hline Serbia & 30.7 & 3.42 & - & 0.24 & 117 \\
\hline Singapore & 18.5 & 2.92 & 0.66 & 1 & 3 \\
\hline South Africa & 19.8 & 2.99 & 0.58 & 0.60 & 10 \\
\hline Spain & 13.4 & 2.60 & 0.64 & 0.36 & 22 \\
\hline Sri Lanka & 18.5 & 2.92 & - & 0.46 & 1357 \\
\hline Sudan & 14.4 & 2.67 & - & 1 & 3 \\
\hline Sweden & 33.8 & 3.52 & 0.87 & 0.57 & 170 \\
\hline Switzerland & 32.1 & 3.47 & - & 0.50 & 10 \\
\hline Syria & 5.5 & 1.70 & - & 0.34 & 79 \\
\hline Tanzania & 44 & 3.78 & - & 0.28 & 18 \\
\hline Thailand & 46 & 3.83 & 0.87 & 0.24 & 21 \\
\hline Trinidad and Tob & 15.1 & 2.71 & 0.73 & 1 & 1 \\
\hline Tunisia & 7.3 & 1.99 & 0.15 & 0.19 & 54 \\
\hline Turkey & 33 & 3.50 & 0.79 & 0.40 & 2144 \\
\hline Ukraine & 47.3 & 3.86 & 0.65 & 1 & 2 \\
\hline United Kingdom & 32.8 & 3.49 & - & 0.53 & 141 \\
\hline United States & 36.4 & 3.59 & 0.63 & 0.43 & 69 \\
\hline Uruguay & 21.1 & 3.05 & 0.93 & 0.60 & 5 \\
\hline Venezuela & 12.5 & 2.53 & - & 1 & 1 \\
\hline
\end{tabular}




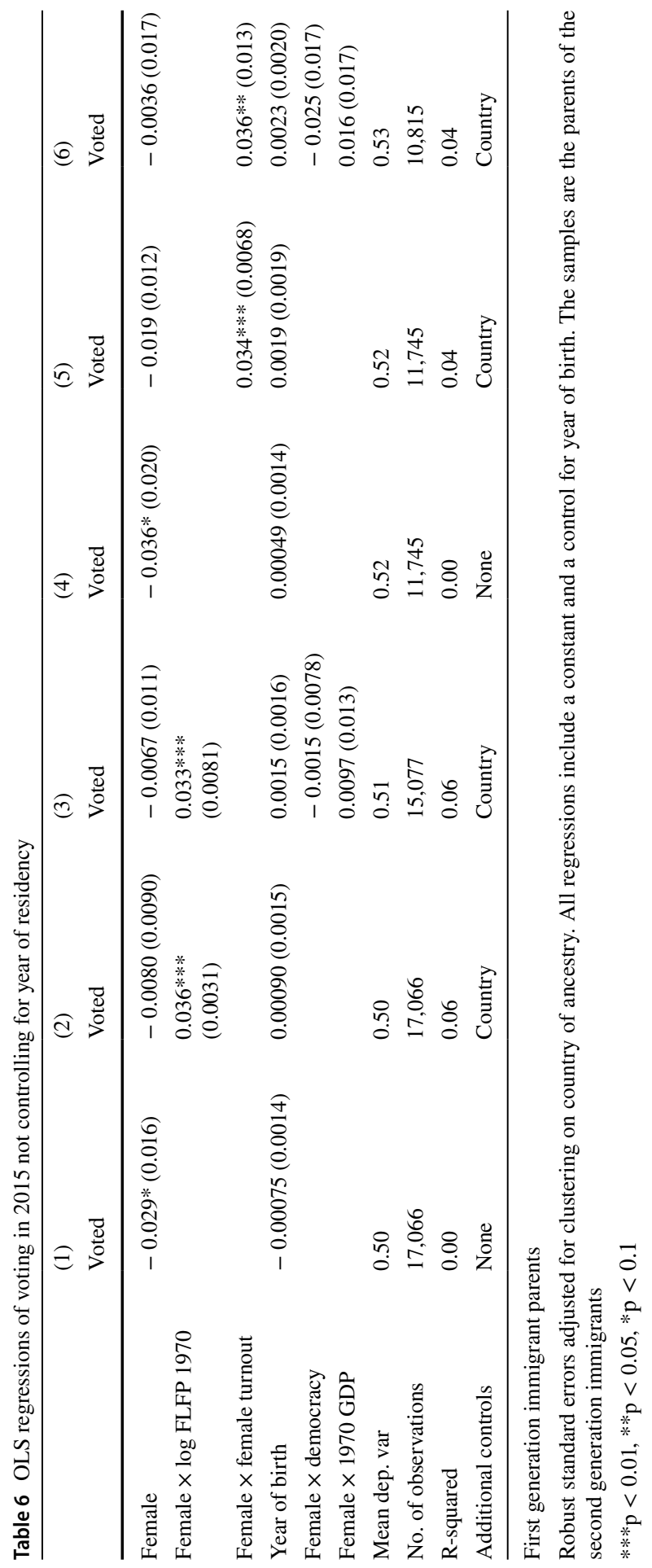




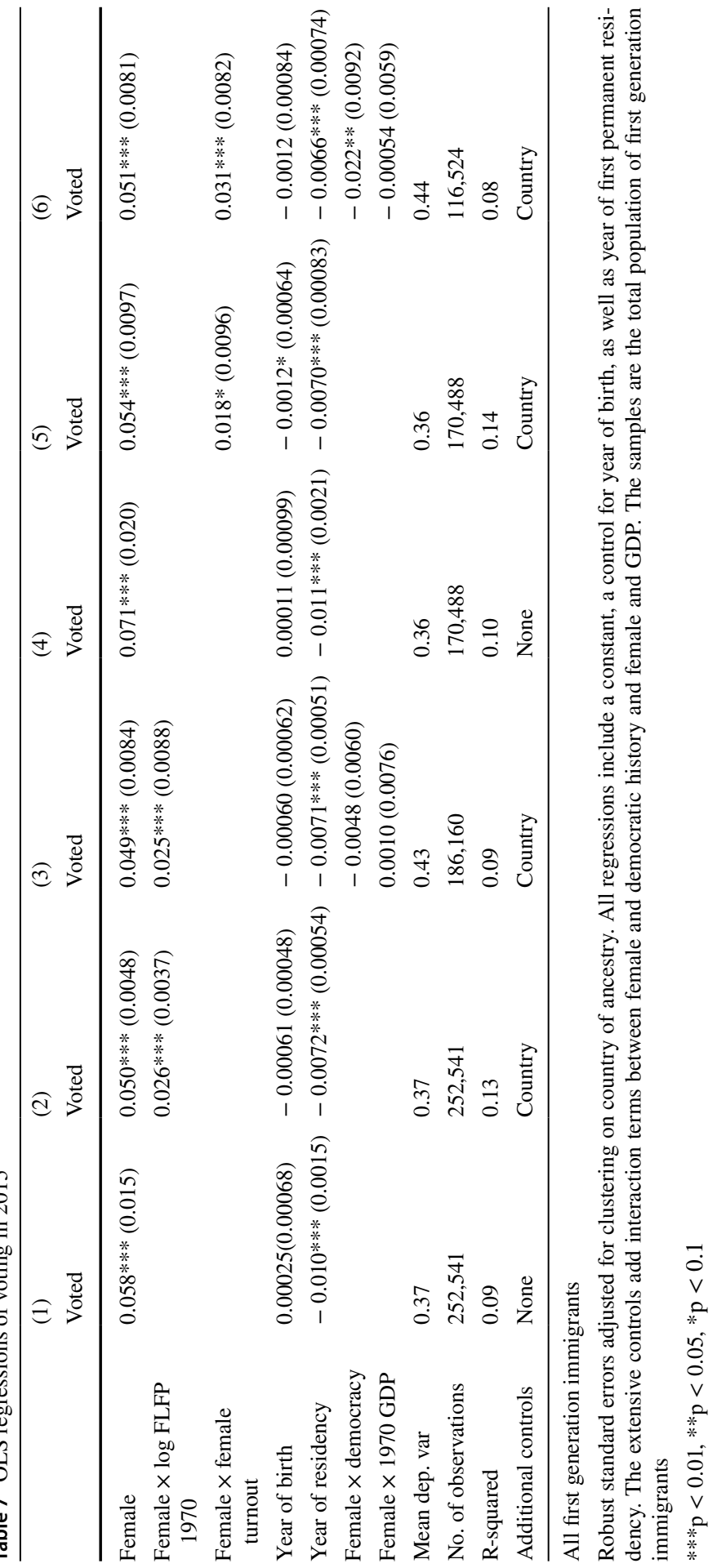


Table 8 OLS regressions of voting in 2015

\begin{tabular}{llll}
\hline & $(1)$ & $(2)$ & $(3)$ \\
& Voted & Voted & Voted \\
\hline Female & $0.026(0.034)$ & $-0.026(0.059)$ & $-0.032(0.064)$ \\
Female $\times$ log FLFP 1970 & $0.0066(0.022)$ & & $-0.012(0.056)$ \\
Female $\times$ female turnout & & $0.021(0.031)$ & $0.033(0.064)$ \\
Female $\times$ democracy & $-0.015(0.022)$ & $-0.049(0.040)$ & $-0.056(0.050)$ \\
Female $\times$ 1970 GDP & $-0.0079(0.036)$ & $-0.038(0.047)$ & $-0.034(0.050)$ \\
Mean dep. var & 0.42 & 0.42 & 0.42 \\
No. of observations & 17,167 & 13,304 & 13,304 \\
R-squared & 0.66 & 0.62 & 0.62 \\
Fixed effects & Family & Family & Family
\end{tabular}

Second generation. Additional controls

Robust standard errors adjusted for clustering on country of ancestry. All regressions include a constant and a control for year of birth as well as country fixed effects. The samples are the total population of second generation immigrants

$* * * \mathrm{p}<0.01, * * \mathrm{p}<0.05, * \mathrm{p}<0.1$

Table 9 OLS regressions of voting in 2015

\begin{tabular}{lll}
\hline & $(1)$ & $(2)$ \\
& Voted & Voted \\
\hline Female & $0.034^{* * *}(0.0079)$ & $0.035^{* * *(0.0100)}$ \\
Female $\times \log$ FLFP 1970 & $-0.0028(0.0074)$ & \\
Female $\times$ female turnout & & $-0.0040(0.0097)$ \\
Year of birth & $-0.0063^{* * *}(0.0011)$ & $-0.0057^{* * *}(0.0014)$ \\
Mean dep. var & 0.55 & 0.54 \\
No. of observations & 89122 & 53048 \\
R-squared & 0.74 & 0.73 \\
Fixed effects & Family & Family \\
\hline
\end{tabular}

Alternative definition of second generation immigrants

Robust standard errors adjusted for clustering on country of ancestry. All regressions include a constant and a control for year of birth. The samples are the total population of second generation immigrants with at least one foreign born parent

$* * * \mathrm{p}<0.01, * * \mathrm{p}<0.05, * \mathrm{p}<0.1$ 


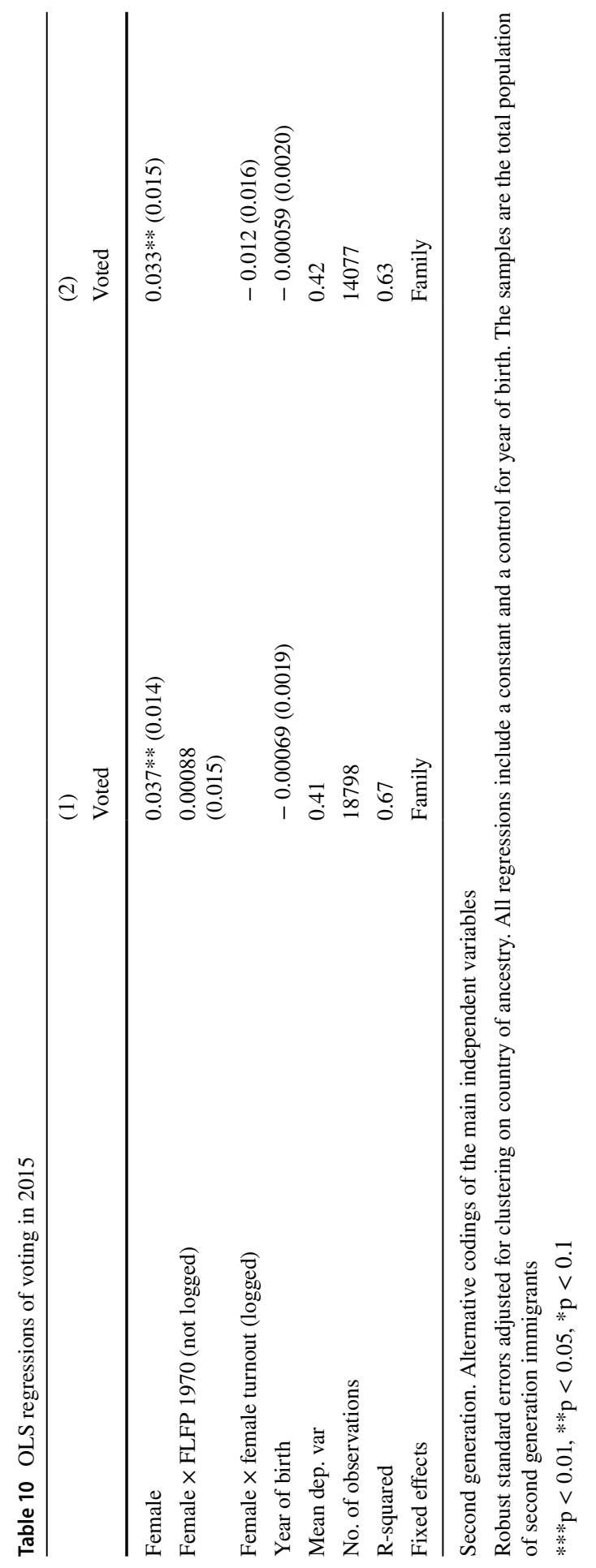




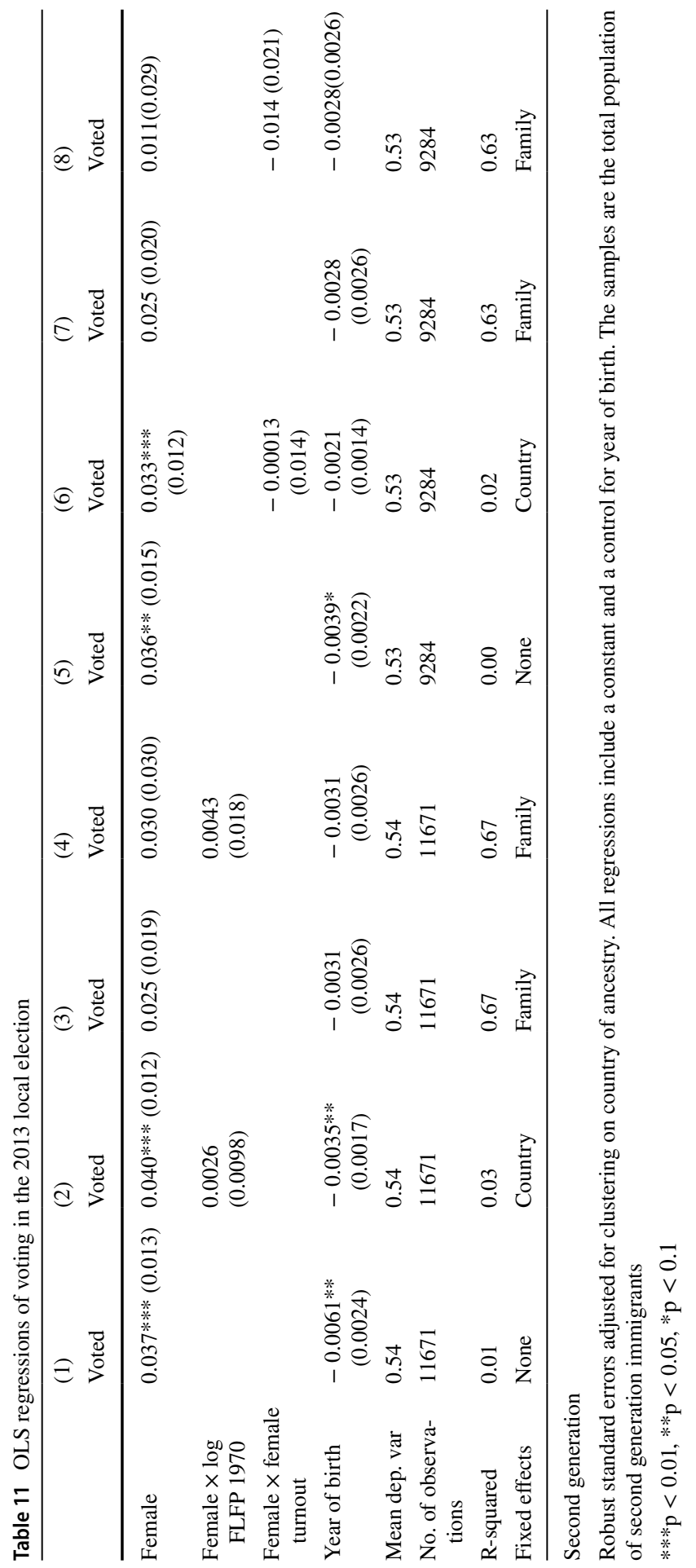




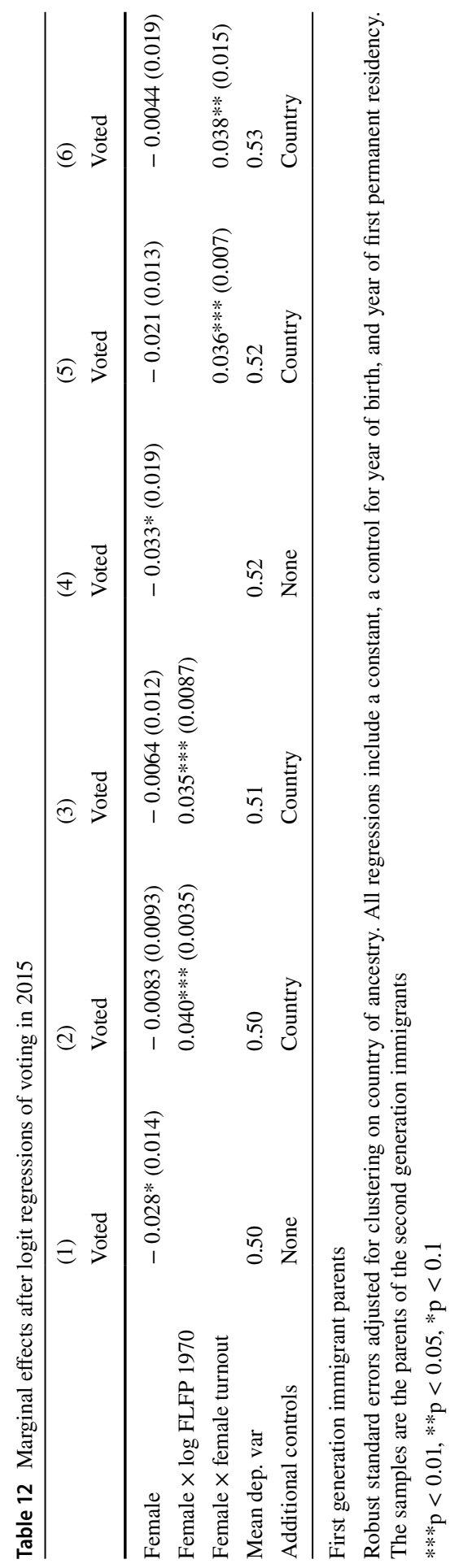




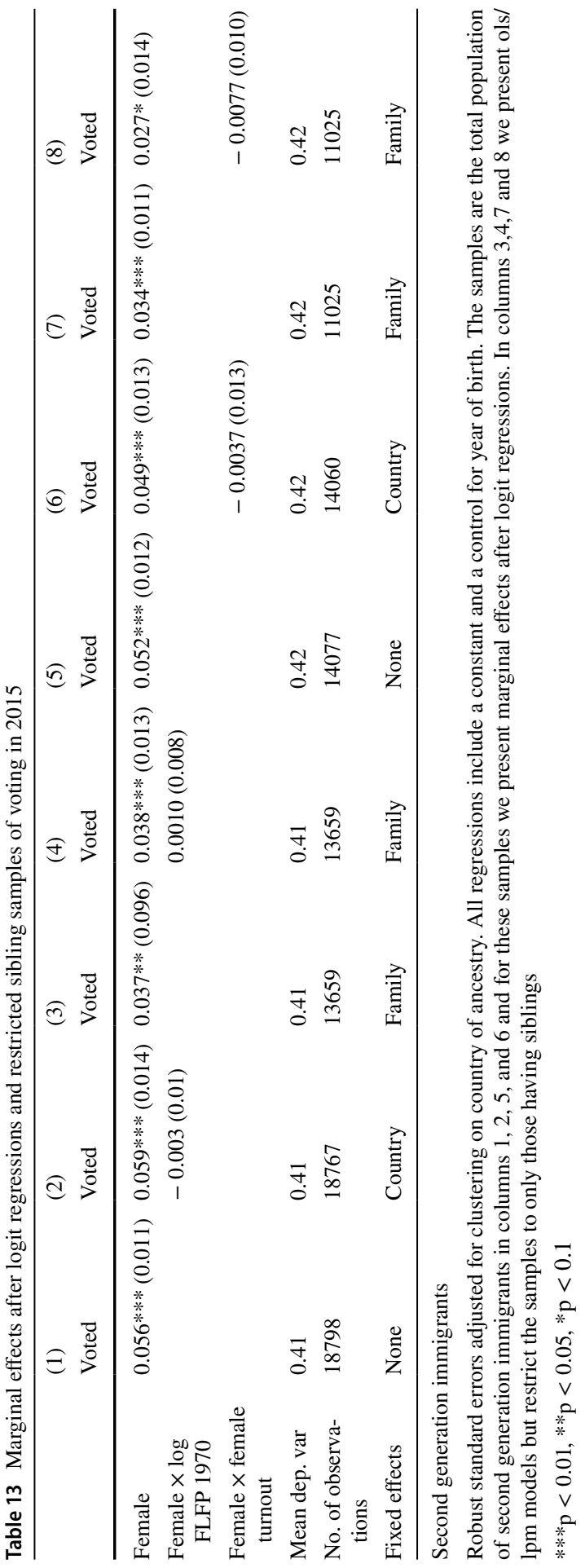




\section{References}

Ai, C., \& Norton, E. C. (2003). Interaction terms in logit and probit models. Economics Letters, 80(1), $123-129$.

Alba, R., \& Nee, V. (1997). Rethinking assimilation theory for a new era of immigration. International Migration Review, 31(4), 826-874.

Alba, R. D., \& Nee, V. (2003). Remaking the American mainstream: Assimilation and contemporary immigration. Cambridge: Harvard University Press.

Almond, G. A., \& Verba, S. (2015). The civic culture: Political attitudes and democracy in five nations. Princeton: Princeton University Press.

Battu, H., Mwale, M., \& Zenou, A. (2006). Oppositional identities and the labor market. Journal of Population Economics, 20(3), 643-667.

Bratsberg, B., Ferwerda, J., Finseraas, H., \& Kotsadam, A. (2019a). How settlement locations and local networks influence immigrant political integration.

Bratsberg, B., Kotsadam, A., Lind, J. T., Mehlum, H., \& Raaum, O. (2019b). Election turnout inequalityinsights from administrative registers.

Campbell, A., Converse, P. E., Miller, W. E., Stokes, E., \& Donald, S. (1960). The American voter. New York: Wiley.

CAWP. (2017). Gender differences in voter turnout. New Brunswick: Eagleton Institute of Politics, Rutgers University.

Chou, W. (2017). Culture remains elusive: Comment on the identification of cultural effects using instrumental variables. American Sociological Review, 82, 435-442.

De Rooij, E. A. (2012). Patterns of immigrant political participation: Explaining differences in types of political participation between immigrants and the majority population in Western Europe. European Sociological Review, 28(4), 455-481.

Denny, K., \& Doyle, O. (2008). Political interest, cognitive ability and personality: Determinants of voter turnout in Britain. British Journal of Political Science, 38(2), 291-310.

Fernández, R. (2007). Women, work, and culture. Journal of the European Economic Association, 5(23), 305-332.

Fernández, R. (2011). Does culture matter? In J. Benhabib, M. O. Jackson, \& A. Bisin (Eds.), Handbook of social economics (pp. 481-510). North-Holland: Elsevier.

Fernández, R., \& Fogli, A. (2009). Culture: An empirical investigation of beliefs. American Economic Journal: Macroeconomics, 1(1), 146-177.

Ferwerda, J., Finseraas, H., \& Bergh, J. (2018). Voting rights and immigrant incorporation: Evidence from Norway. British Journal of Political Science, 50, 713-730.

Finseraas, H. (2017). The effect of a booming local economy in early childhood on the propensity to vote: Evidence from a natural experiment. British Journal of Political Science, 47(3), 609-629.

Finseraas, H., \& Kotsadam, A. (2017). Ancestry culture and female employment: An analysis using second-generation siblings. European Sociological Review, 33(3), 382-392.

Fuchs-Schündeln, N., \& Schündeln, M. (2015). On the endogeneity of political preferences: Evidence from individual experience with democracy. Science, 347(6226), 1145-1148.

Gans, H., \& Sandberg, N. (1973). Ethnic identity and assimilation: The Polish community. New York: Praeger.

Gordon, M. M. (1964). Assimilation in American life: The role of race, religion, and national origins. Oxford: Oxford University Press.

Güveli, A., \& Platt, L. (2011). Understanding the religious behaviour of Muslims in the Netherlands and the UK. Sociology, 45(6), 1008-1027.

Holbein, J. B. (2017). Childhood skill development and adult political participation. American Political Science Review, 111(3), 572-583.

ILO. (2014). ILOSTAT database. Geneva: ILO.

Inglehart, R., \& Norris, P. (2003). Rising tide: Gender equality and cultural change around the world. Cambridge: Cambridge University Press.

Isaksson, A.-S., Kotsadam, A., \& Nerman, M. (2014). The gender gap in African political participation: Testing theories of individual and contextual determinants. Journal of Development Studies, 50(2), 302-318.

Kotsadam, A., \& Finseraas, H. (2013). Causal effects of parental leave on adolescents' household work. Social Forces, 92(1), 329-351. 
Lipset, S. (1960). Martin, political man: The social bases of politics.

Norris, P. (2002). Women's power at the ballot box. Voter turnout since 1945: A global report.

Platt, L., \& Polavieja, J. (2016). Saying and doing gender: Intergenerational transmission of attitudes towards the sexual division of labour. European Sociological Review, 32(6), 820-834.

Polavieja, J. G. (2015). Capturing culture a new method to estimate exogenous cultural effects using migrant populations. American Sociological Review, 80(1), 166-191.

Polavieja, J. G. (2017). Culture as a random treatment: A reply to Chou. American Sociological Review., 82, 444-450.

Polavieja, J. G., \& Platt, Lucinda. (2014). Nurse or mechanic? The role of parental socialization and children's personality in the formation of sex-typed occupational aspirations. Social Forces, 93(1), 31-61.

Pomper, G. M. (1975). Voters' choice: Varieties of American electoral behavior. Mead: Dodd.

Seppälä, N. (2004). Women and the vote in Western Europe. Chapter voter turnout in Western Europe since 1945 , pp. 33-35.

Solijonov, A. (2016). Voter turnout trends around the world. IDEA.

Vernby, K. (2013). Inclusion and public policy: Evidence from Sweden's introduction of Noncitizen Suffrage. American Journal of Political Science, 57(1), 15-29.

Voicu, B., \& Comsa, M. (2014). Immigrants' participation in voting: Exposure, resilience, and transferability. Journal of Ethnic and Migration Studies, 40(10), 1572-1592.

Wass, H., Blais, A., Morin-Chassé, A., \& Weide, M. (2015). Engaging immigrants? Examining the correlates of electoral participation among voters with migration backgrounds. Journal of Elections, Public Opinion and Parties, 25(4), 407-424.

Welch, S. (1977). Women as political animals? A test of some explanations for male-female political participation differences. American Journal of Political Science, 21, 711-730.

Publisher's Note Springer Nature remains neutral with regard to jurisdictional claims in published maps and institutional affiliations. 